InOedia $\quad \begin{aligned} & \text { InMedia } \\ & \text { The French Journal of Media Studies }\end{aligned}$

8.2. $\mid 2020$

What do Pictures Do? (In)visibilizing the Subaltern

\title{
Visibilizing Invisibility, An Introduction
}

\section{Mathilde Arrivé}

\section{(2) OpenEdition \\ Journals}

Electronic version

URL: https://journals.openedition.org/inmedia/2683

DOI: 10.4000/inmedia.2683

ISSN: 2259-4728

\section{Publisher}

Center for Research on the English-Speaking World (CREW)

\section{Electronic reference}

Mathilde Arrivé, "Visibilizing Invisibility, An Introduction", InMedia [Online], 8.2. | 2020, Online since 22 October 2021, connection on 28 October 2021. URL: http://journals.openedition.org/inmedia/2683 DOI: https://doi.org/10.4000/inmedia.2683

This text was automatically generated on 28 October 2021

(c) InMedia 


\title{
Visibilizing Invisibility, An Introduction
}

\author{
Mathilde Arrivé
}

I am invisible, understand, simply because people
refuse to see me. [...] When they approach me
they see only my surroundings, themselves, or
figments of their imagination [...]. That
invisibility to which I refer occurs because of a
peculiar disposition of the eyes of those with
whom I come in contact. A matter of the
construction of their inner eyes [...].
Ralph Ellison, Invisible Man, New York: Random
House, Vintage Books, (1952) 1980, p. 3.

\section{Social Invisibility: A Definition and An Overview}

1 The broadening scope of the socially visible world, along with the shift from voice to image, is seen by many as a hallmark of modernity. ${ }^{1}$ In the wake of "the pictorial turn," ${ }^{2}$ as individuation processes increasingly involve visual identifications, visibility has become a central paradigm of today's social imagination. Whether desired, imposed, refused or denied, chosen or endured, visibility is now both an individual injunction and an institutional rationale, ${ }^{3}$ regarded as the vehicle and guardian of social existence. ${ }^{4}$

Based on these premises, social invisibility characterizes individuals who are excluded from authorized visualities and majority visual discourses, and thus denied access to the social gaze. Invisible women and men are people "without"-without a face, without

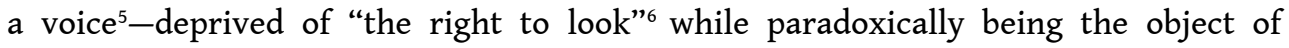
constant surveillance. They may include former colonized people, the poor, the disabled, ethnic and sexual minorities, as well as outsiders, rebels and refugees, but also people living precarious lives or simply anonymous existences, whose images and 
words are relegated to the sidelines of public expression. As philosopher Axel Honneth argues, social invisibility has to be understood metaphorically as "a denial of recognition" sealing "social non-existence" and causing feelings of disaffiliation. In fact, what is commonly called social invisibility (and its corollary, social "inaudibility") is an intersectional phenomenon that encompasses other forms of invisibilityhistorical, political, and legal ${ }^{8}$-particularly among groups or individuals that are also disempowered by race and gender. In her analysis of Howard Cruse's Stuck Rubber Baby (1995), Nathalie Saudo-Welby addresses such intersections of race and gender: she shows that Toland, Cruse's protagonist, liberates his queer voice and achieves visibility as a white gay man, but remains somewhat stuck in a closeting pattern that structures the account of his coming out, while adopting a white middle-class perspective that perpetuates racial normativity.

The array of theoretical and critical thought on invisibility is rich and diverse. The value and significance of "the gaze" has long been an area of investigation among philosophers (Lévinas, Sartre), psychoanalysts (Freud, Lacan) and sociologists (Mauss, Elias). As for the critique of visibility, it constitutes, in itself, a major theoretical tradition, initiated by the Frankfurt School, continued by Foucault, Debord and Barthes, but also Morin and Baudrillard, as well as Sontag, Mitchell and Mirzoeff in the United States. Research on social invisibility, on the other hand, has mainly been the focus of sociology, political science, political philosophy, moral philosophy, and history.

We argue, however, that invisibility has too rarely been approached from the perspective of invisible individuals and through the prism of visual mediations. This special issue therefore proposes to fill these two gaps in order to expand and enrich the nascent field of invisibility studies, but also to shed light on the dual agency of imagesas the vectors of both visibility and opacity, alienation and emancipation, disempowerment and empowerment-focusing not only on how pictures look but also on what they do, ${ }^{9}$ endorse, enact and perform. For social invisibility is not an ontological condition or some essential attribute, but a constructed social situation and a dynamic process, underpinned by institutions and media, discourses and images, which can be revealed and reversed, but also disrupted, subverted and rerouted through various strategies.

5 Ultimately, this issue wishes to sound anew Gayatri Spivak's famous question "Can the Subaltern Speak?" by shifting the emphasis on how the subalterns can see and be seen, raising the issue of their visual expression outside of the restrictive vocabulary borrowed from those in positions of power or knowledge, and the creation of a visual and cultural space where they may appear on their own terms. The articles collected in this issue address different forms of visual art and visual culture, including architecture, painting, (digital) photography, photomontages, comics, graphic memoir, video footage, video installations, movies, and new media. The United States will be a privileged locus of exploration, as a "culture of invisibilization" (Rigaud) paradoxically obsessed with the visible.

6 This exploration shall be conducted in light of the whole new set of questions raised by the recent confinements lockdowns and the generalized use of masks, which have turned invisibility into a common, globally shared experience, redefining the notion of self-image and visual presentation of one's body, altering social interactions, shifting visual attention to new signs, and redistributing the occupation of public space. 


\section{Making Invisibility Visible}

7 Invisibilization is frequently equated with an absence of image. As a result, it has been primarily approached through phenomena of suppression, censorship, relegation, erasure or oblivion..$^{10}$ While social invisibilization may indeed be a downright denial of representation when one is altogether barred from self-imaging, social invisibility can also be a form of misrepresentation and visual control achieved in and via pictures through various strategies-effacing, ghosting, depersonalizing, derealizing, masking, but also essentializing, fetichizing, objectifying, stigmatizing. Laura Singeot shows for example that the erasure of indigenous peoples from the land and their subsequent assimilation come from the colonizers' cultural blindness, resulting in the Aborigines' social and physical invisibility. Strikingly similar in its rationale is the stigma/spectacle of poverty that Éliane de Larminat discusses in her article about public housing residents in Chicago in the 1990s. Oscillating between erasure and fetishization, invisibilizing strategies are visual biases that reveal the workings of the social gazeblind or voyeuristic-grounded in hegemonic epistemologies that deny or obscure the subaltern's singularity and subjectivity and mask the complexity of social agencies. It will thus be paramount to understand the contexts in which visibility, as Foucault famously wrote, becomes "a trap," ${ }^{11}$ when images lose their value as mediations and ossify into stereotypical and reifying patterns. Along similar lines, we will look at instances in which the subalterns seem to internalize and perpetuate their own social invisibility through invisibilizing mechanisms-which are also defense mechanismssuch as social camouflage, racial passing, or masquerade.

Building on these premises, our point is that invisibilization is not necessarily the opposite of visibility: more often than not, invisibilization is in fact visible and can be objectified. We will therefore unpack the apparent paradox of apparatuses (such as biopolitical discipline, ubiquitous surveillance, entertainment, advertising, police profiling, medical or scientific imagery) that invisibilize by way of exposure or overexposure. Let us here quote George Didi-Huberman:

Peoples are exposed to disappearance because they are [...] under-exposed in the shade of their censorship or, with a similar result, over-exposed when they are spectacularly displayed. Under-exposure deprives us of the means to see [...]. But over-exposure is not better: too much light is blinding. Peoples exposed to the stereotyped repetition of images are also peoples exposed to disappear. ${ }^{12}$

9 Instances of hypervisible invisibilization are many, especially if we consider the sexist tendency to give hypervisibility to the female body or the racist tendency to give hypervisibility to the Black body, often framed by conventional media "within sensationalist narratives of spectacular violence" (Poulain) or spectacular desire, as they are either erotized or victimized/criminalized. Antonia Rigaud and Martha Cutter remind us indeed that African Americans, although socially invisible, "have been overly visualized and scrutinized" (Cutter), caught up in "a tradition of hypervisibility" (Rigaud), exemplified by blackface. In contemporary media culture, a paradigmatic example of hypervisible invisibility is the photograph gone viral of a tortured Abu Ghraib inmate with his face covered by a bag-"the Hooded Man," "the Bagman," "the Invisible Man of Abu Ghraib." ${ }^{13}$ Long before that, the myth of the Vanishing Race granted Native Americans abundant visibility, but along the spectralizing and thanatographic lines of an already dead people. 
10 Such examples show that invisibility is not an absence of image, but rather a visual pattern as much as a configuration of the gaze-a way of seeing, a visuality-socialized by arts and the media, both old and new. The collected articles in this issue precisely aim at making apparent the invisible operations of the social gaze and at "highlighting the politics of invisibilization" (Singeot) from a reflexive, decolonial perspective, characteristic of today's alternative epistemologies. To that extent, most pictures presented in this issue may be regarded as "metapictures"14 because they expose invisibilizing mechanisms, thus un-doing and denaturalizing previous imagery.

\section{The "Right to Appear." Visual Sovereignty and Counter- visuality}

11 Why make oneself visible? How to visually "curate" the self (Cutter)? Using what visual language or media circuits? These questions resonate with particular acuteness in today's context of "image wars"15 and fights for visibility, which are also fights for and of representation(s), in the political and theatrical understandings of the word. While the digital turn has made visibility more fluid, less centralized and more horizontal, "the right to appear"16 and to represent oneself is, first of all, a right to look and to look back, but also to (re)appropriate the dominant imagery critically. This may be achieved in counter-images-in bell hooks' words, "the transgressive image[s], outlaw rebel vision[s]" ${ }^{17}$-where visual codes are altogether reversed in a "process of complete reimaging" (Larminat). On the other hand, subtler forms of negotiation may involve parody and humor, plays on codes and identifications, framings, poses, backgrounds and props, intervisual references, collages and montages, resulting in baroque or creolized aesthetics. For example, in Michael Cook's photomontages, visual bricolage is based on palimpsestic layering, which serves as a paradoxical form of unveiling, foregrounding indigenous absence, while, at the same time, generating a visual dialectic-between presence and absence, past and present, freedom and containment -which derails the colonial imperative of transparency and the notion of a unidimensional "Other." In other instances, visual codes, techniques or motifs derived from the world of high art (drapery, sfumato, etc.) are used for counter-hegemonic purposes to "decolonize the canon" (Poulain).

But (re)appropriation of past imagery is only one visibilizing tactic among many others. Also worthy of attention is automediation, the contemporary avatar of $19^{\text {th }}$-century autoethnography, which makes it possible to use agency both inside and in front of pictures and to determine the visual scenario according to one's own singular representational desire or need. Martha Cutter shows for example that, in front of photographers, both Frederick Douglass and Sojourner Truth were able to "manipulate the photographic mise-en-scène to their own benefit" "via curation of objects, expressions, and slogans", thus crafting, staging and performing versions of their identities.

13 As exemplified in this issue, becoming visible often means becoming socially sighted, as invisible people reclaim the capacity not only to look and be looked at in their own terms, but also "to become seers" and "to be seen seeing," 18 to see themselves as seers and to see how they are seen. This is what South African photographer and visual activist Zanele Muholi achieves when creating a visual archive of her community and an "archive of the self"19 (Poulain). This is also what Éliane de Larminat describes when 
public housing residents in Chicago circulated documentary pictures of their own living conditions, thereby "gaining the position of subjects in front of an object-and thus resist[ing] objectification". For at stake is also the invisibility of the viewers. Many images presented in this issue force the emotional response and intellectual engagement of the spectators as well as a reappraisal of their assumptions, blind spots and responsibility in visual politics, either through complex visual puzzles (Muholy) or through direct hailing, when Adrian Piper looks out of the camera into her viewers' eyes to "keep them from hiding from her" (Rigaud).

In the context of digital visibility and its increased democratization of self-images, automediation may assume a more collective significance, especially when it involves group practices of visibility based on participation-marches, assemblies, occupations and other forms of appropriation of the public space. In his article on the Gilets Jaunes (Yellow vests) crisis, André Gunthert analyzes how a minority opinion emerged in the French public debate through alternative media. As Gunthert explains, this counternarrative tapped into strategies borrowed from activist communication (viral images, the alert process, the exposure of violence, and a reading of documentary material) but used them in a distinctive manner that redefined visual activism and its impact on interpretive communities and public opinion. As Gunthert explains, visibility may serve as a new agora, ${ }^{20}$ in which the role of art and the media is then to create an experience and a conversation "on what [visibility] means and how it engages both the self and the viewer” (Rigaud).

These empowering acts of visual sovereignty may offer new forms of "epistemic disobedience" ${ }^{21}$ and new ways of reclaiming subjectivity, identity and participation. But they also involve a wholesale transference of political agency into the realm of the visible. Interestingly, Jacques Rancière describes the political experience as an aesthetic one:

a delimitation of spaces and times, of the visible and the invisible, of speech and noise, that simultaneously determines the place and the stakes of politics as a form of experience. Politics revolves around what is seen and what can be said about it, around who has the ability to see and the talent to speak. ${ }^{22}$

But as the visual and the political become intertwined, even confused, especially with the ubiquity of new media, visibility itself may in fact become the public sphere, or even replace it. This is where the constant search for increased visibility begs the question: does it reinforce "the tyranny of visibility" 23 and its normative practices, or does it use the vocabulary of visibility to renew, enrich, or even undermine it? ${ }^{24}$

Ultimately, we are interested in the emergence of counter-visualities-that is, according to Nicholas Mirzoeff, "dissensus with visuality, [...] dispute[s] over what is visible" ${ }^{25}$ likely to delineate another visual order, another visual configuration of the social world, a new "distribution of the sensible." ${ }^{16}$ For, in the end, the issue of (in)visibility is "not so much about an expansion than a reconfiguration of the visual field" (Singeot), a process in which counter-images have a role to play-to redefine the social contract, to reorganize political bodies and to reshuffle the distribution of attention in the public sphere, maybe outside of the perimeter of the strictly visible. 


\section{Towards Post-visuality: Invisibility as Tactic?}

18 While some individuals are over-exposed and others unseeable, visuality tends to oscillate between two opposite scopic regimes, the spectacular and the spectralresulting sometimes in their deadly association, as in acts of terror, which combine images of destruction and the destruction of images. ${ }^{27}$ In her discussion of Muholi's work, Alexandra Poulain reminds us that "while invisibility is a form of social death, visibility also means heightened vulnerability." This existential split signals a crisis of visibility ${ }^{28}$-simultaneously regarded as value and anti-value, ${ }^{29}$ trap and privilege, source of emancipation and subjugation-which also indicates a crisis in institutions ${ }^{30}$ and a crisis of subjectivities. These observations, in turn, invite a radical critique of the primacy of visibility and make room for the premise that invisibility itself may, in fact, be a source of visual agency and a form of visual sovereignty. What kind of presence, action, expression and creativity, if any, does invisibility enable or foster?

Rémi Lauvin usefully reshistoricizes "the art of being unseen" by showing that it has been part and parcel of the early history of film: vanishing figures (blurred or fleeting) are a visual trope providing both a counterpart to figures of authority (police forces) and a counterpoint to the art of cinema conceived as a celebration of vision and a demiurgic capture of the visible. Although invisibility is commonly construed as transgressive because of its association with crime, sex, violence and resistance to established power-but also with all things sacred (transcendence is invisible because it is incommensurable)-this issue wishes to bring to the fore situations of chosen invisibility, used as a protective, even defensive, strategy against optical scrutiny and visual control. Martha Cutter defines Douglass's and Truth's avatars as "visual shields," keeping the "real" individual safe behind layers of disguise, manipulation, and performance. Similarly, Oliver Klaassen explains that, within a context of continual and potentially life-threatening experiences of surveillance and monitoring, gay artist of color Dean Sameshima photographed deserted private rooms and empty beds in a men's spa and club. By turning absence, camouflage and opacity into protective tools, Sameshima "queers the visual sphere"-a queerness meant as a counter-surveillance tactic (Klaassen). In this instance, semi-(in)visibility is not experienced as a form of loss, self-censorship, or giving up of representations, but rather as a form of resistance and as a critique of visual politics.

Many minority artists refuse monumental, spectacular and theatrical selfdramatizations, developing instead "tactics based on subtraction, lack, uncertainty or invisibility." ${ }^{31}$ Adrian Piper opts indeed for invisibility on many levels: in her passing as white, in her choice of conceptualism (with its eclipse of pictures), and in her repeated and deliberate disappearing acts of withdrawal, retreat, or refusal to comply with institutional logic (Rigaud). This is where invisibility becomes a form of radical iconoclasm.

21 Articles in the issue also delve into the various visual strategies that run counter to the traditional codes of self-exposition: paradoxical portraits, back views, faces concealed or out of frame, etc., leading to visual aporias that combine ostentation and dissimulation, in "a paradoxical game of appearing and disappearing" (Poulain). Alexandra Poulain tells us about Muholi's photographs of her black skin against a dark background, in an act of deliberate "unselfing" of her project so as "to embody invisible others," and to embody the suffering, resilience and resistance of Black bodies. By 
challenging viewers to see, self-erasure is a way to "escape the hold of objectifying systems of knowledge," "to trouble the regime of omissions and exclusions which sustains it," but also to fully embrace vulnerability.

Yet the paradox of invisibility is that what is invisible also excites the imagination and amplifies the production of images, especially in the digital age. This is what Rémi Lauvin argues: faced with the routinization of new forms of identification techniques, in particular facial recognition devices, invisibility has now become "the product of an excess" rather than a retention, lying in "the parasitic accumulation of visual elements" and "information overload." In our contemporary era, hypervisibility and surveillance therefore seem to invite invisibility under a new guise-that of "selffalsification" and "self-counterfeiting", resulting in "a parade of shifting, volatile identities" (Lauvin). Are these "volatile identities" forms of "post-identities" and "ordinary singularities" in Agamben's perspective-identities without identification and without image, detached from communities that could recognize and represent them?

In today's era of "post-visuality," ${ }^{32}$ we may instead hope for reflexive images capable of revitalizing mediations, activating the social gaze in a fresh way, and favoring the emergence of alternative epistemologies, creating in turn new ways of relating to oneself and to the world.

\section{BIBLIOGRAPHY}

Agamben, Giorgio. La communauté qui vient. Théorie de la singularité quelconque. Paris: Seuil, 1990.

Althusser, Louis. “Idéologie et appareils idéologiques d'état: notes pour une recherche." In Sur la Reproduction, 263-306. Paris: PUF, [1970] 2011.

Aubert, Nicole and Claudine Haroche. "Être visible pour exister : l'injonction à la visibilité ». In Les tyrannies de la visibilité, edited by Nicole Aubert and Claudine Haroche, 7-22. ERES Sociologie clinique, 2011.

Berger, Martin A. Seeing through Race, a Reinterpretation of Civil Rights Photography. Berkeley and Los Angeles: California UP, 2011.

Berger, Martin A. Sight Unseen. Whiteness and American Visual Culture. Berkeley, Los Angeles, London: California UP, 2005.

Boidy, Maxime. "Luttes de représentation, luttes de visibilité." Hybrid 4, (2017). http:// www.hybrid.univ-paris8.fr/lodel/index.php?id=842 <accessed on September 20, 2021>

Brighenti, Andrea Mubi. Visibility in Social Theory and Social Research. Basingstoke: Palgrave McMillan, 2010.

Brunet, François. La photographie, histoire et contre-histoire. Paris: PUF, 2017.

Butler, Judith. Precarious Life, the Powers of Mourning and Violence. London, New York: Verso, 2004. 
Butler, Judith. Rassemblement: Pluralité, performativité et politique. Paris: Fayard, 2016 (Notes Toward a Performative Theory of Assembly, Harvard UP, 2015).

Butler, Judith. "Rethinking Vulnerability and Resistance." In Vulnerability in Resistance, edited by Judith Butler, Zeynep Gambetti and Leticia Sabsay. Durham: Duke UP, 2016.

Crary, Jonathan. Techniques of the Observer: on Vision and Modernity in the Nineteenth Century. Cambridge (Mass.), London: MIT Press, 1992.

Dayan, Daniel. "Conquering Visibility, Conferring Visibility: Visibility Seekers and Media Performance." International Journal of Communication 7, (2013): 137-153.

De Certeau, Michel. L'invention du quotidien, Les Arts de faire (Vol. 1). Paris: Gallimard, 1990.

Debord, Guy. La Société du spectacle. Paris: Gallimard, (1967) 1992.

Didi-Huberman, Georges. Peuples exposés, peuples figurants. L'CEil de l'histoire 4. Paris: Minuit, 2012.

Faes, Hubert. L'invisibilité sociale. Approches critiques et anthropologiques. Paris: L'Harmattan, 2013.

Glissant, Edouard. Poétique de la relation. Paris: Gallimard, 1990.

Gunthert, André. "La visibilité des anonymes. L'accès des images amateur à l'espace public." L'image sociale (9 novembre 2018). http://imagesociale.fr/6657 <accessed on September 20, 2021> Gunthert, André. "Le destinataire inconnu, ou la communication sociale." L'image sociale (21 octobre 2018). https://imagesociale.fr/6605<accessed on September 20, 2021>

Gunthert, André. “À l'envers du selfie,” L'image sociale (25 septembre 2018). http:// imagesociale.fr/6457 <accessed on September 20, 2021>

Gunthert, André. "Printemps sans visage," L'image sociale (12 mai 2018). http://imagesociale.fr/ $6155<$ accessed on September 20, 2021>

Heinich, Nathalie. “Une valeur controversée: les critiques savantes de la visibilité.” In Les tyrannies de la visibilité, edited by Nicole Aubert et Claudine Haroche, 303-321. ERES Sociologie clinique, 2011.

Heinich, Nathalie. De la visibilité: excellence et singularité en régime médiatique. Paris: Gallimard, 2012.

Honneth, Axel. "Visibilité et invisibilité. Sur l'épistémologie de la « reconnaissance »." Revue du MAUSS 23, no. 1, (2004): 137-151.

Joschke, Christian. “À quoi sert l'iconographie politique?” Perspective 1, (2012): 187-192. https:// journals.openedition.org/perspective/646 <accessed on September 20, 2021>

Král, Françoise. Social Invisibility and Diasporas in Anglophone Literature and Culture: The Fractal Gaze. Basingstoke: Palgrave Macmillan, 2014.

Latour, Bruno. "What is Iconoclasm? or Is There a World Beyond the Image Wars." In Iconoclash, Beyond the Image-Wars in Science, Religion and Art, edited by Bruno Latour and Peter Weibel. Cambridge, Mass: MIT Press, 2002.

Le blanc, Guillaume. L'invisibilité sociale. Paris: PUF, 2009.

Marche, Guillaume. “Why Infrapolitics Matters,” RFEA 131 (2012): 3-18.

Mirzoeff, Nicholas. The Right to Look. A Counterhistory of Visuality. Durham: Duke UP, 2011.

Mitchell, W.J.T. Cloning Terror: The War of Images, 9/11 to the Present. Chicago UP, 2011.

Mitchell, W.J.T. Picture Theory. Essays on Verbal and Visual Representation. Chicago UP, 1994. 
Morrison, Toni. The Origin of Others. Cambridge, Massachusetts: Harvard UP, 2017.

Mulvey, Laura. "Visual Pleasure and Narrative Cinema." In Film Theory and Criticism: Introductory Readings, edited by Leo Braudy and Marshall Cohen, 833-44. New York: Oxford UP, 1999.

Pratt, Mary Louise. Imperial Eyes, Travel Writing and Transculturation. London: Routledge, 1992.

Purdie-Vaughns, Valerie and Richard P. Eibach. "Intersectional Invisibility: The Distinctive Advantages and Disadvantages of Multiple Subordinate-Group Identities." Sex Roles 59, (2008): 377-391. https://pdfs.semanticscholar.org/e961/3e98e20385f103ccc9a6fb02028446a01e31.pdf $<$ accessed on September 20, 2021>

Rancière, Jacques. Le partage du sensible, esthétique et politique. Paris: La Fabrique, 2000.

Riviere, Joan. "Womanliness as a Masquerade." The International Journal of Psychoanalysis 10, (1929): 303-313.

Soutif, Daniel (ed.). The Color Line, Les artistes africains-américains et la ségrégation (1865-2016). Paris: Coédition Flammarion/Musée du Quai Branly, 2016.

Spivak, Gayatri Chakravorty. “Can the Subaltern Speak?” In Colonial Discourse and Post-Colonial Theory: A Reader, edited by Patrick Williams and Laura Chrisman, 66-111. London, 1993.

Sun, Wei. Minority Invisibility, an Asian American Experience. Lanham: University Press of America, 2007.

Tehranian, John. Whitewashed America's Invisible Middle Eastern Minority. New York: NYU Press, 2010.

Thompson, John B. “La nouvelle visibilité.” Réseaux 129-130, no. 1, (2005): 59-87.

Zawadzki, Paul. "Le regard vertical." In Les tyrannies de la visibilité, edited by Nicole Aubert et Claudine Haroche, 293-302. ERES Sociologie clinique, 2011.

\section{NOTES}

1. See Walter Benjamin, "L'œuvre d'art à l'heure de sa reproductibilité technique," in CEuvres, Tome III (Paris: Gallimard, 2000), 269-316. See also Jonathan Crary, Techniques of the Observer: on Vision and Modernity in the Nineteenth Century (Cambridge, Mass., London: MIT Press), 1992.

2. W.J.T. Mitchell, Picture Theory. Essays on Verbal and Visual Representation (Chicago and London: Chicago UP, 1994).

3. Paul Zawadzki, "Le regard vertical," in Les tyrannies de la visibilité, eds. Nicole Aubert et Claudine Haroche (ERES Sociologie clinique, 2011), 293-302.

4. Axel Honneth, "Visibilité et invisibilité. Sur l'épistémologie de la " reconnaissance ", Revue du MAUSS 23, no. 1, (2004): 137-151.

5. See Arlette Farge, Sans visages. L'impossible regard sur le pauvre (Paris: Bayard, 2004); Guillaume Garcia, La cause des 'sans'. Sans-papiers, sans-logis, sans-emploi à l'épreuve des médias (Rennes: PUR, 2013) ; Jacques Guilhaumou, La Parole des Sans. Les mouvements actuels à l'épreuve de la Révolution française (Lyon: ENS éditions, 1998).

6. Nicholas Mirzoeff, The Right to Look: A Counterhistory of Visuality (Durham: Duke University Press, 2011), 481-83.

7. Voir Céline Braconnier et Nona Mayer, Les inaudibles. Sociologie politique des précaires (Paris: Presses de Sciences Po, 2015) ; Jean-Paul Payet et al. (eds.), La voix des acteurs faibles. De l'indignité à la reconnaissance (Rennes: PUR, 2008). 
8. Valerie Purdie-Vaughns and Richard P. Eibach, "Intersectional Invisibility: The Distinctive Advantages and Disadvantages of Multiple Subordinate-Group Identities," Sex Roles 59, (2008): 377-391. https://pdfs.semanticscholar.org/e961/3e98e20385f103ccc9a6fb02028446a01e31.pdf <accessed on September 20, 2021>.

9. On "image acts," see W.J.T. Michell, What Do Pictures Want? The Lives and Loves of Images (Chicago: the University of Chicago Press, 2005) and Horst Bredekamp, Théorie de l'acte d'image (Paris: La Découverte, 2015).

10. See "Erased, Replaced, Omitted, Denied: American Art and Negation," Workshop at Institut national d'histoire de l'art, April 1, 2015. See also "Donner la parole aux sans-voix, le phototexte engagé," conference at MSH Paris Nord, May 31-June 1, 2018 ; "Pour une iconographie politique des dominés," seminar organized by LabToP/CRESPPA and coordinated by Maxime Boidy.

11. Michel Foucault, Discipline and Punish, trans. Alan Sheridan (New York: Vintage, 1995), 200, cited by Cutter.

12. Georges Didi-Huberman, Peuples exposés, peoples figurants (Paris: Éditions de Minuit, 2012), 15. Translated and cited by Singeot.

13. W.J.T. Mitchell, Cloning Terror: The War of Images, 9/11 to the Present (Chicago UP, 2011),140-141.

14. "Pictures about pictures," "pictures that refer to themselves," "pictures that are used to show what a picture is," "pictures [that are] capable of providing a second-order discourse that tells us -or at least show us-something about pictures." W.J.T. Mitchell, Picture Theory, 35-38.

15. Bruno Latour, "What is Iconoclasm? or Is There a World Beyond the Image Wars?" in Iconoclash, Beyond the Image-Wars in Science, Religion and Art, eds. B. Latour and P. Weibel (Cambridge, Mass: MIT Press, 2002).

16. Judith Butler, Precarious Life, the Powers of Mourning and Violence (London, New York: Verso, 2004).

17. bell hooks, Black Looks. Race and Representation (1992; New York and London: Routledge, 2015), 20. Cited by Poulain.

18. Alievitna Hervy, "Que signifie être visible? Réflexions sur l'invisibilité sociale à partir d'Axel Honneth et de Guillaume Le Blanc," Lille, May 22, 2014, Transphilosophiques: 4. https:// orbi.uliege.be/bitstream/2268/178671/1/Que signifie être visible .pdf<accessed on September 20, 2021>

19. Muholi cited by Poulain.

20. André Gunthert, "La visibilité des anonymes. L'accès des images amateur à l'espace public," L'image sociale (9 novembre 2018). http://imagesociale.fr/6657 <accessed on September 20, 2021>

21. Walter Mignolo, "Epistemic Disobedience and the Decolonial Option," Transmodernity: Journal of Peripheral Cultural Production of the Luso-Hispanic World 1, no. 2, (Fall 2011): 44-66. Cited by Poulain.

22. Idem.

23. Nicolas Aubert et Claudine Haroche, Les tyrannies de la visibilité (ERES Sociologie clinique, 2011). https://www.cairn.info/les-tyrannies-de-la-visibilite--9782749213507.htm <accessed on September 20, 2021>

24. Maxime Boidy, "Luttes de représentation, luttes de visibilité," Hybrid 4,(2017). http:// www.hybrid.univ-paris8.fr/lodel/index.php?id=842 <accessed on September 20, 2021>

25. Nicholas Mirzoeff, The Right to Look. A Counterhistory of Visuality (Durham: Duke UP, 2011), 24.

26. Jacques Rancière, The Politics of Aesthetics, The Distribution of the Sensible, Transl. Gabriel Rockhill (London, New York: Continuum, 2004, 2011), 13-14.

27. Mitchell, Cloning Terror, 64.

28. Boidy, "Luttes de representation."

29. Nathalie Heinich, "Une valeur controversée: les critiques savantes de la visibilité," in Les tyrannies de la visibilité, eds. Nicole Aubert et Claudine Haroche, 303-321.

30. Zawadzki, "Le regard vertical," 294. 
31. Description of the exhibition "L'art de la discretion," curated by Quentin Jouret at Espace Écureuil in Toulouse (24 Nov. 2017- 24 Feb. 2018), Toulouse, France.

32. Mirzoeff, The Right to Look, 277.

\section{ABSTRACTS}

This introduction seeks to clarify and question the contours and stakes of social (in)visibility. After an overview of the theoretical and critical thought on the issue, this paper will move on to the debates in the field of visual culture studies and to present the main avenues of inquiry opened by each contribution in this issue: invisibilizing strategies and the role of institutions, individual or collective struggles for visibility, counter-practices and alternative forms of visual agency and visual sovereignty. It will then venture to consider invisibility itself as a possible tactic in the age of post-visuality.

\section{INDEX}

Keywords: visual culture, image theory, social invisibility, identities, post-visuality

\section{AUTHOR}

\section{MATHILDE ARRIVÉ}

Mathilde Arrivé is Associate Professor at Université Paul-Valéry Montpellier 3, France, where she teaches American history, politics, and arts since 2010. An agrégé in Anglophone studies and a specialist in American visual culture, she is the author of the monograph Le primitivisme mélancolique d'Edward S. Curtis (PULM, 2019, 322 p.).

EMMA, EA741 - Université Paul-Valéry Montpellier 3 